\title{
Bovine kappa-casein gene polymorphism and its association with milk production traits
}

\author{
Satyanarayana Rachagani and Ishwar Dayal Gupta \\ Dairy Cattle Breeding Division, National Dairy Research Institute, Karnal, Haryana, India.
}

\begin{abstract}
Point mutations in exon IV of the bovine $\kappa$-casein (CSN3) gene determine two allelic variants, $\mathrm{A}$ and $\mathrm{B}$. These variants were distinguished by polymerase chain reaction and restriction fragment length polymorphism (PCR-RFLP) analysis in the indigenous Sahiwal and Tharparkar cattle breeds. DNA samples (252 Sahiwal and 56 Tharparkar) were analyzed for allelic variants of the CSN3 gene. Polymorphism was detected by digestion of PCR-amplified products with Hindll, Hhal and Haell restriction enzymes, followed by separation on $3 \%$ agarose gels, and resolved by ethidium bromide staining. Allele $A$ of the $\kappa$-casein gene occurred at a higher frequency than allele $B$, in both Sahiwal and Tharparkar breeds. The genotypic frequencies of $A A, A B$, and BB in the Sahiwal and Tharparkar breeds were $0.758,0.230$ and 0.012 , and $0.0 .732,0.250$ and 0.018 , respectively. The frequencies of alleles $A$ and $B$ in the Sahiwal and Tharparkar breeds were 0.873 and 0.127 , and 0.857 and 0.143 , respectively. Genotype BB of the kappa-casein gene had more influence on the monthly milk yield, 305-days milk yield, monthly solids-not-fat (SNF) yield, and monthly protein yield, in the Sahiwal cattle.
\end{abstract}

Key words: Indian cattle, $\kappa$-casein, genetic polymorphism, PCR-RFLP.

Received: May 25, 2007; Accepted: April 1, 2008.

Milk protein genetic polymorphism has received considerable research interest in recent years because of possible associations between milk protein genotypes and economically important traits in dairy cattle. Many research reports have indicated that certain milk protein variants may be associated with milk production (Ng-Kwai-Hang et al., 1984; Bech and Kristiansen, 1990), milk composition (Lunden et al., 1997; Ng-Kwai-Hang, 1998; Robitaille et al., 2002) and cheese production (van den Berg et al., 1992; Lundén et al., 1997; Ng-Kwai-Hang, 1998). Therefore, milk protein genes could be useful as genetic markers for additional selection criteria in dairy cattle breeding. The main components of the cow milk casein complex are $\alpha \mathrm{s} 1$, $\alpha s 2, \beta$ and $\kappa$-caseins, and each one of them is known to occur in the form of two or more variants, inherited according to a straight-forward Mendelian model. The $\kappa$-casein (CSN3) molecule is a single-chain polypeptide of 169 amino acids with a molecular weight of 19.2 KDa. CSN3 plays an important role in milk chemistry by providing colloidal stability to the casein micelle. In the micelle, $\kappa$-casein is mostly located at the periphery, with its hydrophilic $\mathrm{C}$-terminal sequence protruding into the solvent. The K-ca-

Send correspondence to Ishwar Dayal Gupta. Dairy Cattle Breeding Division, National Dairy Research Institute, Karnal, Haryana 132001, India. E-mail: idgdcb59@yahoo.co.in, satyarachagani@ redifmail.com. sein gene has been assigned to chromosome $6(6 \mathrm{q} 31)$ in cattle (Threadgill and Womack, 1990). Two K-casein variants have been described in detail as $\mathrm{K}$-casein $\mathrm{A}$ and $\mathrm{B}$. The difference between A and B lies in single amino acid substitutions at positions 136 and 148 (Eigel et al., 1984). The present study aimed at genotyping Sahiwal and Tharparkar cattle breeds for the $\kappa$-casein gene and at finding out whether there is an association between $C S N 3$ polymorphic forms and production traits in Sahiwal cattle. Blood samples were collected in vacutainers (Becton Dickinson Vacutainer System) containing sodium EDTA as an anticoagulant from Sahiwal (252) and Tharparkar (52) cattle breeds maintained at the National Dairy Research Institute, India. Genomic DNA was extracted from $10 \mathrm{~mL}$ of whole blood by the phenol-chloroform method, as described by Sambrook et al. (1989), and from semen, as described by Lien et al. (1990). The quality of the DNA was checked on $0.6 \%$ agarose gel and the quantity was determined by UV spectrophotometry at $\mathrm{A}_{260} / \mathrm{A}_{280} \mathrm{~nm}$.

The sequence (GenBank Accession \# AY380229) reported by Robitaille et al. (2005) was used for primer designing by using the Primer3 software (Rozen and Skaletsky, 2000) to amplify the $633 \mathrm{bp}$ PCR product that consists of a part of intron III (4 bp), exon IV (516 bp) and intron IV (113 bp). The primer sequences were: 5'-CAG CGC TGT GAG AAA GAT GA -3' (forward) and 5'-CCC 
ATT TCG CCT TCT CTG TA -3' (reverse). The PCR amplification reaction contained $100 \mathrm{ng}$ DNA, $50 \mathrm{ng} / \mu \mathrm{L}$ of each primer $0.5 \mathrm{ug}, 1.5 \mathrm{mM} \mathrm{MgCl} 2,200 \mu \mathrm{M}$ of dNTPs, PCR buffer ( $15 \mathrm{mM} \mathrm{MgCl}_{2}, 100 \mathrm{mM} \mathrm{KCl}, 20 \mathrm{mM}$ Tris-HCl pH 8.0, 0.1 mM EDTA, 1 mM DTT, 0.5\% Tween 20 (V/V), $0.5 \%$ Igepal, and $50 \%$ glycerol) and 0.9 units of Taq DNA polymerase. The fragment was amplified by hot-start PCR, in which $2 \mu \mathrm{L}$ of genomic DNA $(50 \mathrm{ng} / \mu \mathrm{L})$ were overlaid with $1.5 \mu \mathrm{L}$ of mineral oil in a PCR tube. PCR amplification was carried out in a programmable thermal cycler (MJ Research) as follows: denaturation at $95{ }^{\circ} \mathrm{C}$ for $5 \mathrm{~min}$, then the temperature was lowered to $85^{\circ} \mathrm{C}$, immediately the PCR master mix was added at the top of the mineral oil. The PCR reaction then proceeded with: $2 \mathrm{~min}$ at $93{ }^{\circ} \mathrm{C}, 1 \mathrm{~min}$ at $94{ }^{\circ} \mathrm{C}, 30 \mathrm{~s}$ at $60^{\circ} \mathrm{C}, 1.45 \mathrm{~min}$ at $72^{\circ} \mathrm{C}$, followed by $29 \mathrm{cy}$ cles of $1 \mathrm{~min}$ at $94{ }^{\circ} \mathrm{C}, 30 \mathrm{~s}$ at $60^{\circ} \mathrm{C}$ and $1.45 \mathrm{~min}$ at $72{ }^{\circ} \mathrm{C}$, and a final extension cycle of $15 \mathrm{~min}$ at $72{ }^{\circ} \mathrm{C}$. The PCR products were loaded onto $1.5 \%$ agarose to confirm the amplification of the target region using a $100 \mathrm{bp}$ marker. Restriction digestion of the PCR product was carried out with enzymes HindIII, HaeIII, and $H h a \mathrm{I}$, and the reaction was set up with $2.0 \mu \mathrm{L}$ of $\mathrm{ddH}_{2} 0,2.5 \mu \mathrm{L}$ of restriction endonuclease buffer 2 (New England Biolabs), 0.6 units of restriction enzymes, and $20.0 \mu \mathrm{L}$ of PCR product incubated at $37^{\circ} \mathrm{C}$ for about $3 \mathrm{~h}$. The restriction-digested fragments were separated on $3 \%$ agarose gels. The gels were stained with ethidium bromide and photographed by using a gel documentation system (Axygen Pvt. Ltd.), and the three genotypes were scored manually. Milk samples $(80 \mathrm{~mL})$ were collected three times a day (morning, afternoon, evening) from all lactating animals in a clean sterile $125-\mathrm{mL}$ polypropylene container, taken to the laboratory and stored at $4{ }^{\circ} \mathrm{C}$. The next morning, three milk samples from each animal were kept at room temperature for $1 \mathrm{~h}$ and mixed well, and about $100 \mathrm{~mL}$ of pooled samples were taken for fat (electronic milk tester method), total protein (Kjeldahl's method), and solids-not-fat (lactometer) analysis.

Data of the Sahiwal cattle of known pedigree and with normal lactation were included in the study. A lactation period of at least 100 days, in which the cow calved and dried under normal physiological conditions, was considered as normal lactation. Data were classified according to parity (lactation I, II, III IV, V and VI) and season [winter (Dec-March), summer (April-June), rainy (July-August), autumn (Sept-Nov)]. Four periods (set of bulls used for AI purpose over a period) and three stages of lactation $\left[1^{\text {st }}\right.$ stage (7-90 days), $2^{\text {nd }}$ stage (91-180 days), $3^{\text {rd }}$ stage (181305 days)] were also considered, to find out the effect of non-genetic factors on performance traits. The numbers of the Tharparkar animal herd were so small that there were no data available on production traits.

Statistical analysis was carried out at the Computer Centre, NDRI. In order to study the effect of season, parity, period and stage of lactation on various traits and to over- come the problem of non-orthogonality of effects due to unequal and disproportionate sub-class frequencies, least-squares analysis of fitting constants as suggested by Harvey (1987) was employed for data analysis. The following fixed linear model was used, with the assumptions that the different components fitted into the model were linear, independent and additive.

$$
Y_{i j k l}=\mu+P_{i}+S E_{j}+P A_{k}+S L_{l}+e_{i j k l}
$$

where $Y_{i j k l}=$ observation of animal of $i^{\text {th }}$ period of $j^{\text {th }}$ season, $k^{\text {th }}$ parity, $t^{\text {th }}$ stage of lactation, $\mu=$ overall mean, $P_{i}=i^{\text {th }}$ effect of period (1...4), $S E_{j}=j^{\text {th }}$ effect of season (1.. 4), $P A_{k}=k^{\text {th }}$ effect of parity $(1 \ldots 6)$ and $S L_{l}=l^{\text {th }}$ effect of stage of lactation (1...3) and $e_{i j k l}=$ random error.

Association between polymorphism patterns and performance traits (monthly and tri-monthly milk yield, 305day milk yield, fat percentage and yield, protein percentage and yield, and SNF percentage and yield) was tested using category variables (genotypes) in adjusted data, as follows:

$$
Y_{i}=\mu+G_{i}+e_{i}
$$

where $Y_{i}=j^{\text {th }}$ production trait of animal in $i^{\text {th }}$ genotype, $\mu=$ overall mean, $G_{i}=$ effect of $i^{\text {th }}$ genotype and $e_{i}=$ random error.

The difference of means between monthly milk yield, tri-monthly milk yield, fat percentage and yield, protein percentage and yield and SNF percentage and yield within season, parity, period, stage of lactation and genotypes was tested for significance by applying Duncan's Multiple Range Test (DMRT) as modified by Kramer (1957).

Restriction digestion of the $633 \mathrm{bp}$ PCR product with enzyme HindIII revealed three genotypes AA (633 bp uncut), $\mathrm{AB}(633,423$ and $210 \mathrm{bp})$ and $\mathrm{BB}(423$ and $210 \mathrm{bp}$ ). The frequencies of genotypes $\mathrm{AA}, \mathrm{AB}$, and $\mathrm{BB}$ were, respectively, 0.758, 0.230 and 0.012 in Sahiwal, and 0.732, 0.250 and 0.018 in Tharparkar cattle. The gene frequencies were calculated based on Mendelian inheritance, and the frequencies of genes A and B were found to be, respectively, 0.873 and 0.127 in Sahiwal, and 0.857 and 0.143 in Tharparkar. The frequency of genotype AA was higher than that of BB in both breeds studied. These results also show that the chosen primers were adequate for amplifying the $\kappa$-casein gene exon IV sequence in Bos indicus cattle. Restriction digestion of the $633 \mathrm{bp} \mathrm{PCR} \mathrm{product} \mathrm{with} \mathrm{en-}$ zymes HaeIII and HhaI revealed 610 and 23 bp for HhaI and 343 and $290 \mathrm{bp}$ fragments for HaeIII in both breeds studied. This indicates that digestion with these enzymes did not reveal any polymorphism in any of the breeds studied.

The frequency found for allele A was higher than that of allele $\mathrm{B}$, which was in close agreement to the results of earlier studies performed in Bos taurus (Ng-Kwai-Hang et al., 1984; Pinder et al., 1994; Kemenes et al., 1999). The genotyping results of Sahiwal and Tharparkar breeds found are similar to those reported for Korean native cattle, Japa- 
nese brown, Angus, Hereford, Charolais and Holstein cows by Chung et al. $(1995,1998)$. Similar observations were reported by Malik et al. (2000) in fourth-generation crossbred cattle (50\% Holstein, 25\% Jersey, 25\% Zebu, i.e., Haryana and Sahiwal cattle).

The present study was the first attempt to associate the genotype with phenotypic data in Sahiwal cattle. The significance of various non-genetic factors influencing production traits is summarized in Table 1, and data were adjusted for significance effects. For the association studies, the adjusted data were used.

The least-squares means of monthly milk yield, tri-monthly milk yield and 305-days milk yield, monthly milk fat percentage and yield, monthly milk protein percentage and yield, monthly milk SNF percentage and yield for different genotypes are presented in Table 2. The mean monthly and 305-days milk yield in different $\mathrm{K}$-casein variants were, respectively, $206 \pm 1.62 \mathrm{~kg}, 188 \pm 2.84 \mathrm{~kg}$ and $239 \pm 9.92 \mathrm{~kg}$, and $1548.71 \pm 42.41 \mathrm{~kg}, 1336.65 \pm 2.04 \mathrm{~kg}$ and $2284.74 \pm 292.12 \mathrm{~kg}$ in genotypes AA, AB and BB. The animals with genotype BB had a higher monthly and 305-days milk yield than those with genotypes $\mathrm{AA}$ and $\mathrm{AB}$. A similar effect had been noticed by Lin et al. (1986), who reported that the $\mathrm{BB}$ genotype had a higher average milk yield than $\mathrm{AA}$ and $\mathrm{AB}$, and the lactational yield values were 4244, 4280 and $4465 \mathrm{~kg}$ for genotypes AA, AB and BB, respectively. Alison Van Eenennaam and Medrano (1991) compared $\kappa$-casein $\mathrm{AA}$ and $\mathrm{BB}$ genotypes and showed that the BB genotype showed first lactational yields increased by $296 \mathrm{~kg}$ with regard to AA. In contrast, Gonyon et al. (1987) and Curi et al. (2005) reported that the K-casein genotype AA was associated with higher milk production than $\mathrm{BB}$, with the heterozygous $\mathrm{AB}$ being intermediate, whereas Ng-Kwai-Hang et al. (1986) and S Kim, M.Sc. Thesis, McGill University, Montreal, QC, 1994) showed that $K$-casein $\mathrm{AB}$ animals were better milk producers than either of the homozygous animals, in Ayrshire, Holstein,
Jersey, brown Swiss, Canadienne and Guernsey cattle breeds. This is indicative of variations among species, environments and management practices adopted at different farms.

The mean monthly fat percentage and fat yield in different $K$-casein variants were $4.92 \pm 0.11,4.79 \pm 0.19$ and $4.91 \pm 0.68 \mathrm{~kg}$, and $10.31 \pm 0.32,9.10 \pm 0.56$ and $11.94 \pm 1.93 \mathrm{~kg}$ in genotypes $\mathrm{AA}, \mathrm{AB}$ and $\mathrm{BB}$, respectively. $\mathrm{BB}$ animals had a higher monthly fat yield than those with genotypes $\mathrm{AA}$ and $\mathrm{AB}$. However, the results were not statistically significant. The results of the present study are in concurrence with those of Ng-Kwai-Hang et al. (1986), Horne et al. (1997) and Strzalkowska et al. (2002), who also reported that the $\kappa$-casein variant $\mathrm{BB}$ genotypes were associated with increased milk fat yield. The mean monthly protein percentage and yield in the $\mathrm{AA}, \mathrm{AB}$ and $\mathrm{BB} \kappa$-casein genotype variants were $3.61 \pm 0.018,3.58 \pm 0.030$ and $3.67 \pm 0.136 \mathrm{~kg}$, and $22.91 \pm 0.49,20.96 \pm 0.80$ and $23.28 \pm 3.59 \mathrm{~kg}$, respectively. The AB animals had a lower monthly protein yield compared to those with genotypes $\mathrm{AA}$ and $\mathrm{BB}$, but no significant difference was observed in protein percentage among the genotypes. Similar results were reported by Bovenhuis et al. (1992), Van den Berg et al. (1992), Ron et al. (1994) and Ikonen et al. (1996), whereas Kim (1994) and Strzalkowska et al. (2002) found no difference in the milk protein content between the two K-casein variants in Ayrshire, Jersey, brown Swiss, Canadienne, Guernsey and Polish Black-and-White cattle. The mean monthly milk SNF percentage and yield in the different $\kappa$-casein variants were $8.88 \pm 0.003,8.87 \pm 0.005$ and $8.90 \pm 0.016 \mathrm{~kg}$, and $18.32 \pm 0.14,16.77 \pm 0.25$ and $21.32 \pm 0.88 \mathrm{~kg}$ in genotypes $\mathrm{AA}, \mathrm{AB}$ and $\mathrm{BB}$, respectively. The BB animals had higher monthly SNF percentage and yield than those with genotypes AA and AB. The results of the present study are in concurrence with those of Strzalkowska et al. (2002).

Table 1 - Least-squares variance analysis (mean squares) of lactation traits of Sahiwal cattle.

\begin{tabular}{lrrrrr}
\hline Trait & \multicolumn{1}{c}{ Season } & \multicolumn{1}{c}{ Parity } & \multicolumn{1}{c}{ Period } & Stage of lactation & \multicolumn{1}{c}{ Error } \\
\hline MMY & $218640.88^{* *}$ & $303288.22^{* *}$ & $2681852.0^{* *}$ & $3525942.5^{* *}$ & 9247.58 \\
TMMY & $341527.84^{*}$ & $542197.94^{*}$ & $5731153.50^{*}$ & $3497162.50^{*}$ & 82531.32 \\
MFP & $13.22^{\mathrm{NS}}$ & $35.14^{\mathrm{NS}}$ & $29.64^{\mathrm{NS}}$ & $26.62^{\mathrm{NS}}$ & 39.99 \\
MFY & $645.98^{\mathrm{NS}}$ & $1152.51^{* *}$ & $7567.20^{* *}$ & $8346.93^{* *}$ & 317.89 \\
MPP & $0.45^{*}$ & $0.15^{\mathrm{NS}}$ & $0.72^{* *}$ & $0.44^{\mathrm{NS}}$ & 0.14 \\
MPY & $535.15^{* *}$ & $709.40^{* *}$ & $6767.37^{* *}$ & $3926.51^{* *}$ & 110.59 \\
MSNFP & $0.05^{\mathrm{NS}}$ & $0.47^{* *}$ & $1.67^{* *}$ & $0.05^{\mathrm{NS}}$ & 0.02 \\
MSNFY & $1746.99^{* *}$ & $2334.86^{* *}$ & $21982.59^{* *}$ & $27760.11^{* *}$ & 72.80 \\
\hline
\end{tabular}

**Significant at $1 \%$ level.

*Significant at $5 \%$ level.

MMY: monthly milk yield; TMMY: tri-monthly milk yield; 305 MY: 305-days milk yield; MFP: monthly fat percentage; MFY: monthly fat yield; MPP: monthly protein percentage; MPY: monthly protein yield; MSNFP: monthly SNF percentage; MSNFY: monthly SNF yield. 
Table 2 - Least-squares means for א-casein (CSN3) genotypes of Sahiwal cattle.

\begin{tabular}{|c|c|c|c|}
\hline Trait/genotype & AA & $\mathrm{AB}$ & $\mathrm{BB}$ \\
\hline Monthly milk yield (kg) & $206.22 \pm 1.62^{\mathrm{a}}(3213)$ & $188.92 \pm 2.84^{\mathrm{b}}(1045)$ & $239.10 \pm 9.92^{\mathrm{c}}(86)$ \\
\hline Tri-monthly milk yield (kg) & $635.46 \pm 13.26^{\mathrm{a}}(439)$ & $584.55 \pm 22.03^{\mathrm{b}}(159)$ & $620.23 \pm 98.22^{\mathrm{ab}}(8)$ \\
\hline 305-days milk yield (kg) & $1548.71 \pm 42.41^{\mathrm{a}}(429)$ & $1336.65 \pm 2.04^{\mathrm{b}}(148)$ & $2284.74 \pm 292.12^{\mathrm{c}}(9)$ \\
\hline Monthly fat percentage $(\mathrm{kg})$ & $4.92 \pm 0.11(3264)$ & $4.79 \pm 0.19(1054)$ & $4.91 \pm 0.68(86)$ \\
\hline Monthly fat yield (kg) & $10.31 \pm 0.32(3205)$ & $9.10 \pm 0.56(1039)$ & $11.94 \pm 1.93(86)$ \\
\hline Monthly SNF percentage $(\mathrm{kg})$ & $8.88 \pm 0.003^{\mathrm{a}}(3264)$ & $8.87 \pm 0.005^{\mathrm{b}}(1054)$ & $8.90 \pm 0.016 \mathrm{a}^{\mathrm{b}}(86)$ \\
\hline Monthly SNF yield (kg) & $18.32 \pm 0.14^{\mathrm{a}}(3209)$ & $16.77 \pm 0.25^{\mathrm{b}}(1045)$ & $21.32 \pm 0.88^{\mathrm{c}}(86)$ \\
\hline Monthly protein percentage $(\mathrm{kg})$ & $3.61 \pm 0.018(446)$ & $3.58 \pm 0.030(159)$ & $3.67 \pm 0.136(8)$ \\
\hline Monthly protein yield (kg) & $22.91 \pm 0.49^{\mathrm{a}}(437)$ & $20.96 \pm 0.80^{\mathrm{b}}(159)$ & $23.28 \pm 3.59^{\mathrm{a}}(8)$ \\
\hline
\end{tabular}

In parentheses: number of observations. a, b, c: values with same superscript do not differ significantly.

We concluded that the genotype frequency of AA was higher than that of BB in the Sahiwal and Tharparkar populations studied, and the frequency of gene A was also higher. At the $\kappa$-casein exon IV locus, HindIII enzyme revealed polymorphism, but HaeIII and HhaI did not. These results further confirm that in Bos indicus cattle the predominant genotype is CSN3 AA, as in European breeds. The kappa-casein gene BB genotype showed a greater influence on monthly milk yield, 305-days milk yield, monthly SNF yield and monthly protein yield. The present study was an aid in the selection of superior animals, i. e, those with genotype BB, in order to increase the production of milk and its constituents without increasing the herd size in India.

\section{Acknowledgments}

The authors thank the National Dairy Research Institute, Karnal, for funding the project and for facilities provided.

\section{References}

Alison Van Eenennaam and Medrano JF (1991) Milk protein polymorphism in California dairy cattle. J Dairy Sci 74:1730-42.

Bech AM and Kristiansen KR (1990) Milk protein polymorphism in Danish dairy cattle and the influence of genetic variants on milk yield. J Dairy Sci 57:53-63.

Bovenhuis H, Van Arendonk JAM and Korver S (1992) Associations between milk protein polymorphism and milk production traits. J Dairy Sci 72:2549-2559.

Chung ER, Han SK and Rhim TJ (1995) Milk protein polymorphism as genetic marker in Korean native cattle. Asian Aust J Anim Sci 8:187-194.

Chung ER, Kim WT and Lee CS (1998) The DNA polymorphism of Kappa casein and beta-lactoglobulin, growth hormone and prolactin genes in Korean cattle. Asian Aust J Anim Sci 11:422-427.

Curi RA, Oliveira HND, Gimenes MA, Silveira AC and Lopes CR (2005) Effects of CSN3 and LGB gene polymorphisms on production traits in beef cattle. Genet Mol Biol 28:262266.
Eigel WN, Butler JE, Ernstrom CA, Farrell EM, Harwalker VR, Jenneas R and Whitney RM (1984) Nomenclature of proteins of cow milk: Fifth revision. J Dairy Sci 67:1599-1631.

Gonyon DS, Mather RE, Hines HC, Haenlein CFW, Arave CW and Gaunt SN (1987) Association of bovine blood and milk polymorphism with lactation traits in Holstein. J Dairy Sci 70:2585-2598.

Harvey WR (1987) Least squares analysis of data with unequal sub-class numbers. ARS H-4, USDA, Washington DC.

Horne DS, Banks MJ and Muir DD (1997) Milk protein polymorphism. Genetic polymorphism of bovine $\kappa$-casein: Effects on renneting and cheese yield. Proceedings of the IDF Seminar Held in Palmerston North, New Zealand, pp 161-181.

Ikonen T, Ruottinen O, Erhardt G and Oiala M (1996) Allele frequencies of the major milk proteins in the Finnish Ayrshire and detection of a new $\kappa$-casein variant. Anim Genet 27:179-181.

Kemenes PA, Regitano LCA, Rosa AJMl, Packer IU, Razook AG, Figueiredo LA, Silba NA, Etchegaray MAL and Coutinho LL (1999) Kappa casein, Beta-lactoglobulin and growth hormone allele frequencies and genetic distances in Nelore, Gyr, Guzera, Caraco, Charolois, Canchim and Santa Gertrudis cattle. Genet Mol Biol 22:539-541.

Kramer CY (1957) Extension of multiple range tests to group correlated adjusted means. Biometrics13:13-18.

Lien S, Rogne S, Brovold MJ and Lestrom A (1990) A method of isolation of DNA from frozen semen (AI) bull semen. J Anim Breed Genet 10:74.

Lin CY, McAllister AJ, Ng-Kwai-Hang KF and Hayes JF (1986) Effects of milk protein loci on first lactation production in dairy cattle. J Dairy Sci 69:704-712.

Lunden A, Nisson M and Janson L (1997) Marked effect of $\beta$-Lactoglobulin polymorphism on the ratio of casein to total protein in milk. J Dairy Sci 80:2996-3005.

Malik S, Kumar S and Rani R (2000) kappa casein and beta casein alleles in cross bred zebu cattle from India using polymerase chain reaction and sequence specific oligo nucleotide probes. J Dairy Sci 67:295-300.

Ng-Kwai-Hang KF (1998) Genetic polymorphism of milk proteins: Relationship with production traits, milk composition and technological properties. Can J Anim Sci 78 (Suppl):131-147.

Ng-Kwai-Hang KF, Hayes JE, Moxley JD and Monardes HG (1984) Association of genetic variants of casein and milk se- 
rum protein with milk fat and protein production in dairy cattle. J Dairy Sci 67:835-40.

Ng-Kwai-Hang KF, Hayes JF, Moxley JD and Monardes HG (1986) Relationship between milk protein polymorphism and major milk constituents in Holstein-Friesian cows. J Dairy Sci 69:22-26.

Pinder SJ, Perry BN, Skidmore CJ and Savva D (1994) Analysis of polymorphism in the bovine casein genes by use of the polymerase chain reaction. Anim Genet 22:11-20.

Robitaille G, Britten M, Morisset J and Petitclerc D (2002) Quantitative analysis of $\beta$-Lactoglobulin $A$ and $B$ genetic variants in milk of cows $\beta$-Lactoglobulin $\mathrm{AB}$ throughout lactation. $\mathrm{J}$ Dairy Sci 69:651-654.

Robitaille G, Britten M, Morisset J and Petitclerc D (2005) Polymorphism in the bovine kappa casein (CSN3) gene and the 5'-flanking region: Sequence analysis of CSN3 A and B alleles. Anim Genet 36:185-185.

Ron M, Yoffe O, Ezra E, Medrano JF and Weller JI (1994) Determination of effects of milk protein genotypes on production traits of Israeli Holsteins. J Dairy Sci 77:1106-1113.

Rozen S and Skaletsky HJ (2000) Primer3 on the WWW for general users and for biologist programmers. Primer3 on the WWW for general users and for biologist programmers. In:
Krawetz S and Misener S (eds) Bioinformatics Methods and Protocols: Methods in Molecular Biology. Humana Press, Totowa, pp 365-386.

Sambrook J, Fritsch EF and Maniatis T (1989) Molecular Cloning: A Laboratory Manual. 3rd edition. Cold Spring Harbour, Cold Spring Laboratory Press, New York.

Strzalkowska N, Krzyzewski J and Ryniewicz Z. (2002) Effects of $\kappa$-casein and $\beta$-lactoglobulin loci polymorphism, cow's age, stage of lactation and somatic cell count on daily milk yield and milk composition in Polish Black-and-White cattle. Anim Sci Paper Rep 20:21-35.

Threadgill DW and Womack JE (1990) Genome analysis of the major bovine milk protein genes. Nucleic Acids Res 18:6935-6942.

Van den Berg G, Escher JTM, De Koning PJ and Bovenhuis M (1992) Genetic polymorphism of $\kappa$-casein and $\beta$-lactoglobulin in relation to milk composition and processing properties. Neth Milk Dairy J 46:145-68.

Associate Editor: Luiz Lehmann Coutinho

License information: This is an open-access article distributed under the terms of the Creative Commons Attribution License, which permits unrestricted use, distribution, and reproduction in any medium, provided the original work is properly cited. 